\title{
Miranda
}

Revue pluridisciplinaire du monde anglophone /

Multidisciplinary peer-reviewed journal on the English-

speaking world

$12 \mid 2016$

Mapping gender. Old images ; new figures

\section{The Palimpsest Girl in Ice by Anna Kavan}

\section{Céline Magot}

\section{OpenEdition}

\section{Journals}

Electronic version

URL: http://journals.openedition.org/miranda/8675

DOI: $10.4000 /$ miranda.8675

ISSN: 2108-6559

\section{Publisher}

Université Toulouse - Jean Jaurès

\section{Electronic reference}

Céline Magot, "The Palimpsest Girl in Ice by Anna Kavan", Miranda [Online], 12 | 2016, Online since 02 March 2016, connection on 16 February 2021. URL: http://journals.openedition.org/miranda/8675; DOI: https://doi.org/10.4000/miranda.8675

\section{This text was automatically generated on 16 February 2021.}

\section{c) (i)}

Miranda is licensed under a Creative Commons Attribution-NonCommercial-NoDerivatives 4.0 International License. 


\title{
The Palimpsest Girl in Ice by Anna Kavan
}

\author{
Céline Magot
}

1 Anna Kavan's last novel Ice is a disturbing, eerie story. It takes place in an unsteady world threatened by impending disasters and destruction: a global war is being waged while the world has entered a "new ice age" (131). Snow and ice are gradually covering the surface of the Earth, which makes movement and travelling difficult. Yet the novel opens on a scene in which the narrator is driving his car to visit "friends in the country" (6), a married couple. The narrator is still attracted by the woman of the couple who used to be his lover before she left him. She is an albino, referred to as "the girl" throughout the novel. At the beginning of the second chapter the girl vanishes: she leaves home and no one knows where she is. The rest of the novel stages constant action yet it does not have a plot as such: it is an account of the narrator's obsessive hunt for the girl, who is in turn dead or alive, a fugitive, a guest or a prisoner in a rapid succession of scenes. The text thus displays the double paradox of an endless chase in a frozen, end-of-the-world context.

2 The object of the quest, the girl, seems both inaccessible and unreal. To use E. M. Forster's categories, it could be said that she is both round and flat: she is "constructed round a single idea or quality" (an attractive elusive girl), yet she keeps changing in this unsettling story. In fact, she is a multi-layered construction. Of course any fictitious character might be defined as a construction: a creation of the author as well as an expression of the narrator's voice. But the girl is a construction within the boundaries of the narrative too, and she is mostly that: her identity, function and characterization are the expression of intra and extra-diegetic voices that interweave and superimpose. She is a palimpsest character whose body, especially her hair, becomes the concrete expression of those multiple echoing voices, gives shape to them.

The novel opens on a tense, dark atmosphere: "I was lost, it was already dusk" (5). From those very first words the focal character and first-person narrator appears as a voice that may be unable to come to terms with the world around him, and increasingly so: "It had got quite dark by now, and I was soon more hopelessly lost than ever" (5). As he 
is driving his car on his way to visit the girl and her husband, looking at the dark, desolate surroundings, the narrative establishes his problematic vision which both foreshadows and sheds light on his later perception of the girl:

The sky was black, blacker untended hedges towering against it; and when the headlights occasionally showed roadside buildings, these too were always black, apparently uninhabited and more or less in ruins. [...] A handful of small white stones hit the windscreen, making me jump. It was so long since I had experienced winter in the north that I failed to recognize the phenomenon. The hail soon turned to snow, diminishing visibility [...]. (6-7)

The place shifts from the spreading of an ink-like darkness ("black, blacker", "always black") to the emergence of a white layer, so that the opening landscape mimics the making of a palimpsest: black marks are gradually erased and become less and less readable ("diminishing visibility") while only remains of a previous world can be seen. Ruins are indeed traces of earlier inscriptions in the landscape, "remains of the dead past" (32), in the same way as palimpsests are a layering of texts erased and written over; but as Sarah Dillon underlines, "palimpsests are of such interest to subsequent generations because although the first writing on the vellum seemed to have been eradicated after treatment, it was often imperfectly erased. Its ghostly trace then reappeared" (Dillon 12). Ice depicts a moment of climate change and global war. Old, historic ruins at the beginning are duplicated by newly ruined buildings caused by the war. The world has entered a new ice age in which snow and ice gradually cover the surface of the earth, eradicating and erasing the landscape: "The snow thickened, inexhaustibly falling, incessantly sifting down, spreading a sheet of sterile whiteness over the face of the dying world, [...] obliterating the last trace of man and his works" (146). The earth seems to undergo a palimpsesting process so that although the narrator travels, a colourless, undistinguished landscape of vacancy becomes the backdrop for most of the novel: "It could have been any town, in any country. I recognized nothing. Snow covered all landmarks with the same white padding. Buildings were changed into anonymous white cliffs" (104). Descriptions underline what is missing from the landscapes:

My window overlooked an empty landscape where nothing ever moved. No houses were visible, only the debris of the collapsed wall, a bleak stretch of snow, the fjord, the fir forest, the mountains. No colour, only the monotonous shades of grey from black to the ultimate dead white of the snow. (48)

The place is depicted in the negative with the vocabulary of lack ("empty", "nothing", "no houses", "debris", "collapsed", "no colour", "dead"). Inscriptions on the landscape have been scraped down to mere debris, ghostly ruins.

The girl's first appearance is a ghostly hallucinatory vision in the same snow landscape:

An unearthly whiteness began to bloom on the hedges. I passed a gap and glanced through. For a moment, my lights picked out like searchlights the girl's naked body, slight as a child's, ivory white against the dead white of the snow, her hair bright as spun glass. (7)

7 The passage points to the limits of one world ("hedges") to reveal the vision beyond: "I passed a gap and glanced through" as if the landscape had layers of inscriptions. Underneath lies a white world on which the girl's body is visible. Yet her albino body is itself a white surface, a new layer to be written on. Both landscape and character become blank surfaces for the narrator to project and inscribe his hallucinatory imagination on. They are mentalscapes. The echoing groups of sounds ("began to bloom", "gap and glanced", "moment my", "picked out like", "lights [...] like 
searchlights") mimic the process of creation or illusion in which one element, or layer, reveals and echoes another, then both blend in and entangle. The persistent sounds seem to force their way into the sentence in the way words relentlessly resurrect in a palimpsest. ${ }^{2}$ Sarah Dillon notes:

Although the process that creates palimpsests is one of layering, the result of that process, combined with the subsequent reappearance of the underlying script, is a surface structure which can be described by a term coined by De Quincey 'involuted'. [...] The palimpsest is thus an involuted phenomenon where otherwise unrelated texts are involved and entangled, intricately interwoven, interrupting and inhabiting each other. (Dillon 3-4).

8 The girl's apparition in the landscape follows the same process of layering and haunting. The boundaries between the girl and her surroundings are blurred as if they were interwoven layers: "her hair shimmering violet like the shadows of trees on snow" (136), "snow had fallen between her breasts" (56). The girl's body sometimes shows on the surface of a landscape: "Giant willow trees trailed long green hair in the water" (132). She is inhabited by the landscape since her body is shimmery and white like snow, translucent and fragile like the ice that gradually covers the earth: "the extremely delicate, fine, white skin in the region of eyes and mouth" (16). Her ice-like skin is a transparent surface: "I could see her face, which was always pale, but now drained of colour right to the bone" (56). Her face is a parchment whose surface has been scraped off. Towards the end of the novel the narrator witnesses a scene in which the warden and the girl kill a bear, skin it and cover themselves with the vellum: "The huge skin covered them both, its long white hairs tipped with blood. The snowy thickness hid their two bodies" (136). Layers of white accumulate, as skins are covered by skin that is covered by snow. The narrative stages the constant erasure of what exists to recreate a blank parchment: "her face blank" (96), "her white face blank as paper" (51).

9 The narrator describes the girl's physical appearance again and again so that he writes about her body but also on her body. Laying his hands on her skin seems to be part of the writing process: "I watched the pulse in her neck, still beating fast, presently put out my hand, gently touched the spot with the tip of one finger, then let the hand fall. A skin like white satin, hair the colour of moonlight..." (155). Touching her body causes the re-emergence in the text of comparisons that appeared earlier in the text: "Her skin was like white satin, shadowless in the brilliant moonlight" (56). ${ }^{3}$ Touching is (re)writing and, as the same body is written over, the same text is written over and over: "I leaned forward and touched her cold skin" (54), "Leaning forward, I touched her cold skin, the shallow hollow in her thigh" (56). The echoing low sounds mimic the superimposition of similar layers of words, "the ghostly persistence of the underlying texts" (Dillon 19).

10 The narrator becomes the author of the girl, a figure of authority that constructs her as a palimpsest, hence reifies her. She, in turn, is not allowed her own voice. She is covered with layers of words but her own words are lost. In this contradictory narrative, the girl speaks several times (if in a somewhat feeble and subdued way) ${ }^{4}$ and yet the narrator refers repeatedly to her quietness. Her transparent, voiceless yet omnipresent body contrasts with the narrator's disincarnated voice: his physical appearance is never given while she is seen everywhere, described again and again, yet she is the ghost-like being. In a dialogue scene, her sentences are broken up with dots: "“For you ... I heard the car ... I thought ... I wondered..." (154). Like an underlying, half- 
erased text, her words seem to vanish under layers of other words. Her body language tends to replace her voice, but the meaning is lost: "Her face blank, her bright hair shimmering, she silently moved her head in a way that meant anything, nothing" (96).

11 From being an elusive, self-effaced presence in the first chapter the girl vanishes as early as the second chapter. She leaves home and the narrator launches on a quest to find her. He first searches her belongings for clues and finds pictures - mere surfaces, remains of her: "One of these, in which a lake reflected perfectly her face and her shining hair, I put into my wallet" (18). On the picture the girl and the landscape become interweaving layers again. The emergence of an embedded image of the girl prompts expressions of enclosure and containing in the text ("in which", "into my wallet"), while syntactically the description of the picture is set in an inserted clause. This new layer of representation becomes a permanent vision that is superimposed on reality: "Her picture was always with me, in my wallet and in my head. Now her image appeared in the open wherever I looked" (143). The picture becomes the visible trace of the missing girl, a symptom or proof of her absence in the same way as palimpsests are figures of the re-emerging presence of the erased text.

The act of writing itself is shown in a dichotomy between presence and absence. Early in the story the narrator explains he has a passion for lemurs, his "favourite subject" (19) that appears again and again in his mind: "I had sometimes thought vaguely of writing about the fascinating singing lemurs; now I had a perfect opportunity to describe them before the memory faded" (40). Then the narrator associates the girl and her husband to those animals whose name evokes-and has the same origin as-the lemurs, the spirits of the dead in Ancient Roman mythology. Their ghost-like quality contaminates the text as the narrator is trying to write about them during a ship journey:

I would devote the rest of my time to studying them, writing their history [...].

From the shop on board I bought a big notebook and a stock of ball-point pens. I was ready to plan my work. But I could not concentrate. After all, I had not escaped the past. My thoughts kept wandering back to the girl [...].

I tried to stop thinking about her, to fix my mind on those innocent gentle creatures, their sweet, eerie singing. But she persistently distracted me with thoughts that were less than innocent. Her face haunted me [...]. (72-73)

The indris and the girl become two presences that superimpose and mix in the narrator's mind, reminiscent of the way Thomas De Quincey described the working of the brain: "What else than a natural and mighty palimpsest is the human brain? [...] Everlasting layers of ideas, images and feelings, have fallen upon your brain softly as light. Each succession has seemed to bury all that went before. And yet in reality not one has been extinguished." (De Quincey 346). Sarah Dillon shows how De Quincey's palimpsest stands for "the non-possibility of forgetting, [...] the permanence of the memory traces laid down in the mind" (Dillon 30 ). The narrator repeatedly expresses anxiety at his failing memory, ${ }^{5}$ yet the text stages the constant re-emergence of the past so that the memory of the girl constantly comes to the surface and turns into an obsessive thought.

When the girl is erased from the narrative, she becomes paradoxically omnipresent, a haunting presence in the narrator's mind ("she became my obsession", 6) that forces its way to the surface: 
Her white lost face was everywhere with its too-large eyes, her albino paleness flared like a torch beneath the malignant clouds, drew my eyes like a magnet. She was a shimmer among the ruins, her hair a glittering in the dark day. (143) texts, [that] intersect and neutralize one another" (Kristeva, Desire 36). One of the novel's major intertexts is another story of obsession: Alfred Hitchcock's Vertigo comes to the surface of the text to be repeated and rewritten. In Vertigo Madeleine is killed and hurled off a mission tower by her husband Gavin Elster with the help of his accomplice and lover Judy. He makes sure the murder looks like a suicide by asking Scottie Ferguson to follow his wife Madeleine around: he claims she has been acting strangely lately because she is haunted by her ancestor Carlotta Valdez. He knows that Scottie's fear of heights will prevent him from running after her to the top of the tower. The film haunts the novel in an early scene in which the girl's husband and the narrator climb to the top of a tower:

'Take care!' he warned, laughing. 'You could easily slip here, or lose your balance. The perfect spot for a murder, I always think.' His laugh sounded so peculiar that I turned to look at him. He came up to me, saying: 'Suppose I give you a little push... like this -' I stepped back just in time, but missed my footing and stumbled, staggering on to a crumbling, precarious ledge lower down. [...] 'The fall would have been an accident, wouldn't it? No witnesses. Only my word for what happened. Look how unsteady you are on your feet. Heights seem to affect you.' (12)

The novel rewrites the central elements of the film but exchanges roles and functions: the victim of the push is not the wife but her former lover, the narrator. The scene echoes precisely Scottie's losing his footing during a rooftop chase that causes his fear of heights. His traumatic vertigo is linked to the death of the policeman who falls off the roof and dies while trying to rescue him. Scottie is haunted by the past (the policeman's, then Madeleine's death) in the same way as the narrator of Ice is still affected by the girl's leaving him: "the consequences of the traumatic experience were still evident in the insomnia and headaches from which I suffered" (8). Gavin's warning about his wife's irrational attitude might be echoed in Ice by the girl's husband who 
tells the narrator about "[h]er neurotic behaviour" (18) after she has vanished. Mental disorder is a recurrent theme in the film: when Scottie thinks he is following Gavin's wife through the streets of San Francisco, he is in fact made to follow Judy who impersonates the well-named Madeleine who identifies with "the mad Carlotta" (as the bookstore owner Pop Leibel calls her). She evokes her possible madness: "If I'm mad? That would explain it, wouldn't it?"

The intertextual relation between the two works reveals thematic and structural similarities: in both works the motif of the obsessive quest for a woman is shown in a repetitive, spiralling narrative. The narrator of Ice performs the same actions again and again expressed by the same words that keep reappearing in the text. ${ }^{8}$ The film also stages the re-enactment of the same acts and visions in the same settings. The fundamental act of falling off a roof is performed first by a policeman then by both women and Scottie loses the woman he loves twice in similar circumstances. After Madeleine's death, Scottie cannot help seeing her in other women, sometimes in flashes of blonde hair like the narrator of Ice who constantly sees the girl reappear before his eyes only to lose her soon. He explains how "her image appear[s] in the open wherever he look[s]" (143), an obsessive filter superimposed on reality; similarly the image of Madeleine is endlessly multiplied in Scottie's obsession: in his mind but also in two paintings. ${ }^{9}$ Repetition is also the effect of Scottie's actions: his "'cure' for Madeleine involves bringing her to the scene of her dream in order to convince her of the 'reality' of the place and to force her to remember a previous visit there. [...] Throughout the film, Scottie will be concerned with staging these representations in order to gain mastery over them" (Modeleski 96). The plot spirals into the re-enactment of the same scenes and situations so that Madeleine's and Carlotta's hairdo, a spiralling bun, becomes an image of the film's theme and structure. Madeleine is possessed by her ancestor Carlotta and the film proceeds as if the story was already written out for her, as if she merely re-enacted the past on a palimpsestic mode: it is "a story of a woman who appears to be so obsessed with a female ancestor that she actually becomes that other woman from the past and finds herself compelled to live out the latter's tragic fate" (Modleski 94). The narrator's obsession for the girl in Ice may thus appear as an intertextual rewriting, a re-enactment of Scottie's.

We saw how the authoritative narrator of Ice constructs the girl's body as a blank page, a palimpsest apt to be re-written upon. The making of a silver-blonde haired woman is a central theme of Vertigo. Judy is Elster's construction, made up as a replica of his wife, as Scottie bitterly summarizes: "He made you over, didn't he?" After losing Madeleine Scottie fashions Judy's body in turn: he shapes her into Madeleine, buys her clothes and shoes, ultimately forces her to dye her hair and change its style, the final crucial step. Judy first tries to resist this ultimate transformation and pleads: "Couldn't you like me, just me the way I am? When we first started out, it was so good; we had fun. And... and then you started in on the clothes. Well, I'll wear the darn clothes if you want me to, if, if you'll just, just like me." But he replies: "The color of your hair...", she begs again but he insists: "Judy, please, it can't matter to you." For Scottie, the transformation is only complete when Judy's hair is done in a symbolic spiral, shaped according to his own obsession, and dyed. The albino girl's hair might therefore be a radicalised intertextual echo of Judy's dyed silver-blonde hair, as if the novel took us one step further into colourlessness, to show even more explicitly the construction of a woman as a scraped surface to be written upon. Indeed Judy has no reality to Scottie: she is a material that 
must be written over as Madeleine / Carlotta in the same way as the girl in Ice is a blank page covered with superimposed layers of inscriptions, among which Vertigo. The girl's hair also changes shape and aspect, which the narrator remarks with delight: "Her sparkling hair, sprinkled with silver and parma violets, had been touched with a matching dye; the slight touch of fantasy was especially charming" (119). After her final hair transformation, Judy appears in a white halo, a surreal light that is similar to the atmosphere of the novel and of some of the girl's apparitions (her first materialisation in the narrator's car lights, for example).

Through narration as well as through the subjective camera, it is clear that both male characters perceive fair beauty when they see the object of their quest but the violence inherent in their obsessive transformations of women also comes to the surface. Modleski shows how "Judy is the 'original' woman, who will soon be remade (for the second time) into the fully fetishized and idealized, 'constructed' object of male desire and male 'design"' (Modleski 98). In Vertigo the two male characters create a pattern for all female characters to follow, a prototype of the ideal blonde beauty. Hitchcock has been accused of showing archetypal representations of women in his films. ${ }^{10}$ Modleski argues instead that Vertigo suggests that "femininity in our culture is largely a male construct, a male 'design,' and that this femininity is in fact a matter of external trappings, of roles and masquerade, without essence" (Modleski 92). Ice clearly exposes and denounces those external texts projected onto the girl whose own words are lost or hardly heard. Modleski remarks how "for much of the first part of the film [Madeleine] will be the mute, only half-seen object of man's romantic quest: the eternal feminine" (Modleski 93). Vertigo is in fact one of the most visible underlying layers upon which the novel is written, but the same archetypal models the film is built upon also haunt the novel.

21 Marie-Louise Von Franz describes the archetype as "this profound collective stratum [that] is activated in an individual" which can be expressed "in feelings, emotions, mythical fantasy images, and 'mythical' primal ideas" (Von Franz, Archetypal Dimensions 6). Archetypes are therefore the deepest layers of a collective palimpsest. The narrator's quest is itself an archetypal situation in the course of which his obsessive gaze and mind write collective patterns or structures of representation over the girl's body:

Her wide eyes of a wronged and terrified child accused me from the black holes of smashed windows. Like a perverted child she ran past, soliciting me with big eyes, tempting me with the pleasure of watching her pain, elaborating the worst imaginings of my desire. (143)

This passage reveals quick variations in the roles the girl is cast in: her eyes and childlike appearance are given radically different meanings since she is in turn a victim ("wronged", "terrified") and a provocative Lolita ("perverted", "soliciting me"). The narrator projects his own sadistic fantasy onto her ("tempting me with the pleasure of watching her pain"). In a mise en abyme of the act of seeing, he looks at her eyes through "the black holes of smashed windows" as if the narrator's gaze was filtered and embedded into other eyes, an interposed point of view that traps the elusive girl in a submissive and sexually aggressive portrait. Her body is not only a flashing sign that attracts the narrator's attention: it is written over by the distorting gaze and made attractive in the very construction of its powerlessness and victimization. If the narrator is the main source of the misogynistic glance, he also reports a similarlyoriented collective text. He might be the agent of the girl's subjection or an observer, as 
when the girl is the prisoner of another man who robs her of her agency and power of decision:

Suddenly she gave in, worn out, beaten; she was panting, her face was wet. He tightened his grip slightly, compelled her to look straight at him. To bring the thing to a finish, he stared into her dilated eyes, implacably forced into them his own arrogant, ice-blue gaze. This was the moment of her surrender; opposition collapsed at this point, when she seemed to fall and drown in those cold blue mesmeric depths. Now she had no more will. He could do what he liked with her. (36-37)

The man's power over the girl is transmitted in a sort of hypnotic moment as if she could read in his eyes, in the gaze he lays on her, the script she must compel to. The passage also reads as another mise en abyme of glances: the girl is seen by the narrator through the eyes of another man, as if one could never look at somebody without the filter of a collective text expressed in terms of extreme violence. ${ }^{11}$ The collective pattern that is projected onto the girl's body indeed emanates from other external forces than the narrator - even though he is the main one: "Forced since childhood into a victim's pattern of thought and behaviour, she was defenceless against his aggressive will, which was able to take complete possession of her" (36), "She had been conditioned into obedience since early childhood, her independence destroyed by systematic suppression" (17). The similar sentence construction reveals the uniformity of archetypal patterns imposed upon the girl since her childhood, that is to say from the very first stratum laid upon her body: "Her face wore its victim's look, which was of course psychological, the result of injuries she had received in childhood" (16). The verb "wore" suggests that her facial expression is put on like clothes, an outward covering. Some of the sources that have conditioned the girl are identified in the novel - her husband, the warden, but also her mother: "She was over-sensitive, highlystrung, afraid of people and life; her personality had been damaged by a sadistic mother who kept her in a permanent state of frightened subjection" (8). The narrator repeatedly portrays the girl back in that primal defining moment and associates her to a child, as of the very first appearance of her "naked body, slight as a child's" (7). The comparison gives the narrative a strong hint of paedophilia, which reflects again a sadistic portrait of the narrator; but it also ties in with the archetypal social construction of women as powerless creatures: "a submissive, terrorized child" (51), "a child-victim, terrified and betrayed" (56). ${ }^{12}$ It emphasizes her loss of agency: she is defined as weak, inexperienced and socially incompetent. She is constructed in the image of her social function, so that when the narrator describes her as "weightless", it can be read on a physical, psychological but also social level. ${ }^{13}$ Throughout the novel she is what others have made of her - being constantly called "the girl", it is what she becomes: a girl, instead of a fully formed woman character; but she is also the girl: a generic, stereotypical female body that stands for the eternal feminine. She is a radical expression of Elizabeth Grosz's argument about how society produces bodies:

[...] the body, or rather, bodies, cannot be adequately understood as ahistorical, precultural, or natural objects in any simple way; they are not only inscribed, marked, engraved, by social pressures external to them but are the products, the direct effects, of the very social constitution of nature itself. It is not simply that the body is represented in a variety of ways according to historical, social, and cultural exigencies while it remains basically the same; these factors actively produce the body as a body of a determinate type. (Grosz $\mathrm{x}$ ) 
narrator's text and glance thus produce her, manipulate her image - both literally and figuratively: "I observed her extreme slenderness, felt I could enclose the whole of her with my two hands, even the rib-cage containing her heart. [...] I could imagine how it would feel to take hold of her wrists and to snap the fragile bones with my hands" (56). The narrative shifts from observing to holding, seizing and ultimately breaking, revealing the violence in the stereotypical construction of the girl. Similarly her hair which, we have shown, repeatedly attracts his gaze, is also touched (119), seized, held tightly or pulled (54). Interestingly, there are very few mentions of the fact that the nameless narrator is a man. ${ }^{14}$ It is mainly through his archetypal construction of the girl that the reader is led to feel that he is a man. His aggressive attraction for the girl and brutal force are the main elements in the construction of his own identity. The novel therefore puts readers in a problematic position since they are both made to adopt his obsessive, sadistic point of view and to posit his gender persona by projecting an archetypal vision of men onto him.

The violence of patterns of behaviour imposed on women is a recurrent theme in Kavan's fiction. In Change the Name, published more than 25 years before Ice, a very similar situation is described - a male character projects a powerful glance onto a desired woman, although in milder terms:

A contented smile came on his face as he contemplated his future bride. The girl seemed to have grown prettier during the last few days [...]. Of course, she would never have her mother's striking appearance, but that, in any case, was hardly desirable in a doctor's wife who must, pre-eminently, appear respectable. [...] He would be able to mould her to his own pattern. Most young girls were amenable, and she appeared specially so. (231-32)

Change the Name exposes the social pressure that women are victims of and the way they are constructed, "moulded" by external forces. The socially respectable, velvetgloved hand of Kavan's earlier novel becomes radical in Ice where the violence of gendered social and sexual archetypes is extreme. The "moulding" scene thus becomes literal in a passage of actual submission, in which the narrator sees the girl being raped by the warden: "He leaned further, knelt on the bed, pushed her down with his hands on her shoulders. Will-less, she submitted to him, even to the extent of making small compliant movements fitting her body to his" (37). The warden concretely and literally "mould[s the girl] to his own pattern", to the pressure of his lust and power over her.

In the archetypal gendered construction of the body the girl's hair becomes a place of entangled ties and tensions. It is read as an erotic palimpsest that conceals and reveals her at the same time: "her mouth appeared out of the shining hair, then her wet brilliant eyes, glittering between long lashes" (155), "unclothed except by her shining hair" (62). ${ }^{15}$ Hair is traditionally endowed with a highly symbolical value both in myths and in fairy tales, which are major archetypal texts as Marie-Louise Von Franz has shown: "Fairy tales are the purest and simplest expression of collective unconscious psychic processes. [...] They represent the archetypes in their simplest, barest, and most concise form. In this pure form, the archetypal images afford us the best clues to the understanding of the processes going on in the collective psyche" (Von Franz, Interpretation 1).

Ice shows a strong intertextual relation to the genre of the fairy tale as far as its settings and atmosphere are concerned. ${ }^{16}$ But the girl's body itself bears the inscription of fairy-tale archetypes. Like a lot of fairy-tale characters, she is constructed through a 
single distinctive element that is alluded to repeatedly throughout the story and identifies her - one may think of Little Red Riding Hood or Goldilocks: "A bright strand of glittering blonde hair, almost white, escaped from the hood and blew loose in the wind" (28). In her study of fairy-tales Marina Warner shows how "golden hair tumbles through the stories in impossible quantities" (365), most of the time as the traditional token of fair beauty that runs timelessly through all sorts of narratives: "too-blonde hair always looks like a woman's trying to attract the man," Alfred Hitchcock's Marnie is told by her mother; but the girl in Ice is more than "too-blonde": she is an albino. Her hair is more than an erotically-loaded colour: it is uncommon and extreme, a radical version of archetypal fair beauty. The novel brings to the surface the underlying violence of the construction of such characters, notably Rapunzel whose "magnificent long hair, fine as spun gold" is used as a rope for the witch and the prince to climb up the tower, an action that is echoed and perverted in Ice:

Later she did not move, gave no indication of life, lying exposed on the ruined bed as on a slab in a mortuary. [...] Her head hung over the edge of the bed in a slightly unnatural position, the neck slightly twisted in a way that suggested violence, the bright hair twisted into a sort of rope by his hands. He sat with his hand upon her, asserting his right to his prey. (37)

The girl's hair ties her to the man as one of his possessions, a relation that is reinforced by the obsessive repetition of possessives ("his hands", "his hand", "his right", "his prey"). The girl's body is again a malleable material that is given vague shapes and positions ("slightly unnatural", "slightly twisted", "twisted into") and turns into a corpse so that its description reads like some macabre anatomy. Archetypal texts multiply as the scene is frozen into a tableau reminiscent of pictorial representations of Jupiter and Antiope as painted by Anthony van Dyck or Giuseppe Cesari. The girl's body becomes the place of multiple writings, both mythological and fairy tale archetypes, but the novel reveals the latent violence at play in those representations. In this spiralling narrative the Rapunzel echo is repeated later: "I came upon her by chance, not far away, lying face down on the stones. [...] Her neck had an unnatural twist; a living girl could not have turned her head at that angle: the neck was broken. She had been dragged by the hair, hands which had twisted it into a sort of rope had dulled its silvery brightness" (54). The same expressions are used in both passages ("twisted into a sort of rope", "unnatural") and the same body parts are focused on (her neck and her hair) as if the same stereotypical pattern of violence was applied on the girl's body, over and over. Both scenes merge Eros and Thanatos impulses so that the eroticised body is also a corpse that was touched, possessed and shaped by someone else's hands.

The novel rewrites archetypal texts to show how eroticised bodies are raped and assaulted, how idealised bodies are reified. It stages art works as an instance of the production of bodies - the narrator's text is one of them, of course, but the girl is also turned into a model by her husband who is a painter: "On a winter day she was in the studio, posing for him in the nude, her arms raised in a graceful position. To hold it for any length of time must have been a strain, I wondered how she managed to keep so still; until I saw the cords attached to her wrists and ankles" (19). The girl's body has been stripped to be painted over on a white canvas but the painting is never described in the ekphrastic scene because she is the work that is being produced through sadism and torture. The motionless body, in its fair complexion and incapacity to act, might evoke an ancient statuesque idealised beauty. The novel subverts another archetypal text, the myth of Galatae the ivory statue transformed into a real woman: here the 
painter turns the girl into a blank surface to be covered, into an object that he possesses and keeps immobile. The palimpsestic idealised body bears the marks of this violence: "The cords had left deep red angry rings on the white flesh" (19), or later "The circular marks the cords had left on her wrists would have been red in daylight, but now looked black" (56). ${ }^{17}$ Her body thus reconnects with the violence inherent to archetypes, since -typos stands for model, type or blow, the mark of a blow. Bruises, blood and bites are ink-like patches, traces of the productive violence at work: "On her back blood was still fresh in places, wet and bright red; in other places it had caked black on the white flesh. I looked particularly at one arm, on which the circular marks of teeth stood out clearly" (54). Yet in the endless process of turning the girl into a palimpsest, the marks on her skin are constantly scraped off so that she turns again into a blank layer for a new text to be projected upon her: "I saw her shadowed face looked bruised by emotion, before the bright hair swung forward, concealing it. There was a brief pause, long enough for me to feel a chilly sensation creep over me; the adumbration of emptiness, loss ... of what life would be without her." (121). The girl's hair is both Rapunzel's rope, an instrument of violence used against herself, but also what erases the traces of this violence; it is in turn the writing and the blank surface that causes a suspension of the narrative ("brief pause") and materialises into dots. The expression of the narrator's anguish when facing vacancy is reminiscent of the opening of the novel when the landscape of loss and absence is described. The text pauses, makes a loop then is set back into motion, endlessly.

The girl's body reads like a palimpsest the most visible layer of which is probably the hallucinatory, violent construction created by the narrator's haunting vision. His own psychic portrait reflects on the surface: she is covered in inkblot projections that reveal him in the negative, his obsessive mind and his anguish of forgetting or losing memory when confronted with the landscape of absence represented by snowed-in ruins or when the girl is a blank surface again. But other texts lie underneath his voice: the explicit intertextual relation to Vertigo interweaves with fairy-tales or myths which are the expressions of archetypes, as well as social, cultural and aesthetic echoes. Ice rewrites and distorts all those texts, pushing to the extreme the violence of the production of the female body that they carry out. The repetitiveness of the novel echoes that of Vertigo, but it is also connected to the immutability of the archetype. The girl is a voiceless body, the summation of external pressuring voices. Ice thus genders the motif of the palimpsest by showing the muteness or disarticulated language of a body covered in disincarnated texts of power. Each layer of text leaves a bruise, an imprint soon to be erased, then written over again. The girl's body is political, and as such its significance reaches far beyond the limits of the novel: it is an ideological construction that reveals the effect of misogynistic pressures in a paternalistic society. The novel creates a manifesto body to be inscribed with the symbolic or explicit violence conveyed by archetypal representations and makes it extreme and unbearable. 


\section{BIBLIOGRAPHY}

Bergala, Alain, et al. Brune/blonde: la chevelure féminine dans l'art et le cinéma. Paris: Flammarion, 2010.

De Quincey, Thomas. “The Palimpsest of the Human Brain."1845. Thomas De Quincey: The Collected Writings. David Masson, ed. Vol. XIII. London: A\&C Black, 1890. New York: AMS, 1968.

Dillon, Sarah. The Palimpsest: Literature, Criticism, Theory. London: Bloomsbury, 2007.

Forster, E.M. Aspects of the Novel. 1927. New York: Harvest, 1995.

Genette, Gérard. Palimpsestes, La littérature au second degré. Paris: Seuil, 1982.

Grosz, Elizabeth. Volatile Bodies. Toward a Corporeal Feminism. Bloomington: Indiana UP, 1994.

Kavan, Anna. Ice. 1967. London: Peter Owen, 2006.

---. Change the Name. 1941. London: Peter Owen, 1993.

Krohn, Bill. Hitchcock at Work. London: Phaidon Press, 2000.

Kristeva, Julia. Desire in Language: A Semiotic Approach to Literature and Art. New York: Columbia UP, 1980.

---. Revolution in Poetic Language. 1974. Trans. Margaret Waller. New York: Columbia UP, 1984.

---. Semiotike. Recherches pour une sémanalyse. Paris: Seuil, 1969.

Modleski, Tania. The Women Who Knew Too Much: Hitchcock and Feminist Theory. London: Routledge, 2005.

Von Franz, Marie-Louise. Archetypal Dimensions of the Psyche. Boston: Shambhala, 1997.

---. Archetypal Patterns in Fairy Tales. Toronto: Inner City Books, 1997.

---. The Interpretation of Fairy Tales. 1970. Boston: Shambhala, 1996.

Warner, Marina. From the Beast to the Blonde: on Fairy Tales and their Tellers. London: Random House, 1995.

Films

Vertigo. Dir. Alfred Hitchcock. Paramount. 1958.

Marnie. Dir. Alfred Hitchcock. Universal. 1964.

\section{NOTES}

1. "In their purest form, they are constructed round a single idea or quality [...]. The really flat character can be expressed in one sentence" (Forster 67-68).

2. Sarah Dillon refers to the palimpsest's "defining features of retention and resurrection" (Dillon 34).

3. The satin comparison also appears on page 119. The moonlight association can also be found on pages $8,99,119,143$.

4. The narrator has conversations with her (especially on pages 20 or 108-12) and notes that "she spoke little" (12). Her voice is also heard when she sings (10). 
5. "I had visited the girl and her husband before, and kept a vivid recollection of the peaceful, prosperous-looking countryside round their home. But this memory was rapidly fading, losing its reality" (6). See also pages 40 ("before the memory faded") or 57-58 ("there was a curious unreality about the memory of that scene").

6. "Certain sources of possible information were still available. Hairdressers. Clerks who kept records of transport bookings. Those fringe characters. I went to the places such people frequented, stood about playing the fruit machines until I saw a chance of speaking" (18). The amusing pun on "fringe" alleviates the tension that the text creates in what reads like the parody of a detective story with its underworld, secret atmosphere. The girl's hair is the one detail in the photograph that the narrator points to: "I put the photo away, asked if he'd ever seen hair like that" (89).

7. Sarah Dillon notes that "the prime interest of palimpsests and the palimpsest for De Quincey is their implication in resurrection" (Dillon 30).

8. We saw how the comparisons and metaphors describing the girl's skin and hair were repeated. His endless quest also causes the reemergence of the same terms in the text: "start searching" $(26,99)$, "search" $(18,25,26,53,59,137)$, "see her", "see the girl" or "saw her", "saw the girl" (6, $8,10,14,15,16,24,25,29,42,65,143,147)$, "find her" or "find the girl" $(6,13,18,22,25,59)$.

9. The film shows embedded instances of the fashioning of a woman after a picture. It focuses principally on the painting of Carlotta to which Madeleine supposedly identifies and in which Scottie sees Madeleine, but his friend Marjorie also paints herself after that painting.

10. "In film studies, Hitchcock is often viewed as the archetypal misogynist, who invites his audience to indulge their most sadistic fantasies against the female. Some critics have even argued that Hitchcock's work is prototypical of the extremely violent assaults on women that make up so much of our entertainment today" (Modleski 15).

11. Julia Kristeva has shown that violence belongs to the very nature of literature and intertextuality: "if there exists a 'discourse' which is not a mere depository of thin linguistic layers, an archive of structures, or the testimony of a withdrawn body, and is, instead, the essential element of a practice involving the sum of unconscious, subjective, and social relations in gestures of confrontation and appropriation, destruction and construction - productive violence, in short - it is 'literature,' or, more specifically, the text" (Kristeva 1974, 16).

12. Other comparisons of the girl to a child can be found on pages $10,21,62,76,109,115,143$, 151,153 and 155.

13. "I got hold of her, pulled her up to the slope: it was easy, she was almost weightless" (13). She is shown as a thing that the narrator can literally manipulate ("I lifted her off the chair bodily," 111).

14. The narrator explains he spent time "soldiering" (5); elsewhere the warden tells him "I took you for a man of your word" (44).

15. The narrator stares at the girl combing her hair (66), another intimate, erotically-loaded gesture that alludes to fetishism.

16. We saw that the girl is often perceived in hallucinatory, dream-like scenes that hark back to fairy tales in which precise place and time markers are also absent. The abrupt changes in the landscape and characters' attitudes are also reminiscent of fairy tales where charms can do and undo situations: "Then suddenly it was unnaturally, fearfully cold. The masses of dense foliage all round became prison walls, impassable circular green ice-walls, surging towards her" (19). The landscape turns into a hostile, living force similar to the thick wood and enclosing trees in "Sleeping Beauty". One of the main fairy-tale intertexts of Ice might be Hans Christian Andersen's "The Snow Queen", as far as its storyline is concerned. In "The Snow Queen" a girl, Gerda, is on a quest to find her friend, a boy called Kay, who was captured by the Snow Queen. While the fairy tale stages a boy who is "asleep", frozen by the Snow Queen's kiss, and a girl who actively looks for him, the plot of Ice inverts those functions to return to traditional, archetypal gender roles - 
an active male character looks for a passive, victimized female character. This mirror effect is further developed with the theme of mistaken and uncertain identity, which is recurrent in Ice: in the tale, Gerda sees a sleeping prince's nape and mistakes him for Kay in the same way as the girl's hair in Ice attracts repeatedly the narrator's attention although he is at times unsure whether it belongs to the one he is looking for.

17. Numerous passages describe those marks: "she always appeared as a helpless victim, her fragile body broken and bruised" (8), "she [...] showed her desolate victim's face, features dissolved in tears, eyes black as if set in bruises" (154).

\section{ABSTRACTS}

Anna Kavan's last novel Ice (1967) stages the obsessive quest of a man looking for an albino woman he can never reach. He constantly sees then loses this female character who is simply called "the girl". This article analyses the place of her body in the novel, in particular its construction which appears to be a projection of the man's own mind. Beyond its meaning within the boundaries of the narrative, the girl's body becomes the place of inscription of other texts, among which Alfred Hitchcock's Vertigo but also myths and fairy tales, in a layering of intertextual and archetypal rewritings of the female body.

Le dernier roman d'Anna Kavan, Ice (1967), montre la quête obsessionnelle d'un homme à la recherche d'une femme albinos qu'il ne peut jamais atteindre, qu'il aperçoit et perd sans arrêt. Cet article s'attache à analyser la place du corps de ce personnage féminin simplement nommé «the girl» et surtout sa construction qui semble être une projection de l'esprit du personnage masculin. Au-delà de sa signification à l'intérieur du récit, le corps de la fille devient le lieu d'inscription d'autres textes, parmi lesquels Vertigo d'Alfred Hitchcock mais aussi de mythes et contes de fées, dans un tissu de relations intertextuelles et d'archétypes qui réécrivent le corps féminin.

\section{INDEX}

Keywords: palimpsest, intertextuality, archetypes, fairy tales, identity, body and hair in literature

Mots-clés: palimpseste, intertextualité, archétypes, identité, contes de fées, corps et cheveux dans la littérature

\section{AUTHORS}

\section{CÉLINE MAGOT}

Maîtresse de conférences

Université de Toulouse 2 - Jean Jaurès

celine.magot@univ-tlse2.fr 